Table 1. Formation of Streptolysin $S$ BY Protoplasts and INTACT CELLS.

$\begin{gathered}\text { Time of } \\ \text { incubation } \\ \text { (min.) }\end{gathered}$



30
fra
60
90
120
150
60
90
120
150
180

Amount of hemolysin (H.U.)*

Core Active casein hydrolysate

Protoplasts

$\begin{array}{rr}4 & \\ 40 & 32 \\ 70 & 70 \\ 85 & 43 \\ 85 & 32 \\ 11 & 20 \\ 32 & 20 \\ 35 & 25 \\ 40 & 64 \\ 64 & 32\end{array}$

2
20
40
43
70
8
12
10
16
12

* The hæmolytic unit (H.U.) is the amount of hæmolysin which wil yse half the erythrocytes contained in $1 \mathrm{ml}$. of phosphate-buffered lyse half the erythrocytes contain

medium and by observation through a phase contrast microscope. The protoplasts were collected by centrifugation at 4,000 r.p.m. for $10 \mathrm{~min}$. in the cold and resuspended (concentration of protoplasts, 10 mgm. dry weight per $\mathrm{ml}$.) in the reaction medium containing: sodium succinate $(p \mathrm{H} \quad 7.0) \quad 0.5 M$; magnesium sulphate $0.002 M$; potassium phosphate ( $p \mathrm{H} 7 \cdot 0) \quad 0.03 M$; maltose $0.005 M$; and oligonucleotide fraction. ${ }^{1}$ (the material of yeast ribonucleic acid (core) resistant to pancreatic ribonuclease) $200 \mu \mathrm{gm} . / \mathrm{ml}$., or $100 \mu \mathrm{gm} . / \mathrm{ml}$. of the active fraction of core obtained by chromatography on an 'ECTEOLA' cellulose column. The suspension was incubated at $37^{\circ} \mathrm{C}$. and at appropriate intervals an aliquot was withdrawn, chilled at $-20^{\circ} \mathrm{C}$. and centrifuged at 4,000 r.p.m. for $10 \mathrm{~min}$. in the cold. The hærnolytic activities in the supernatants were determined using a freshly prepared, 3 per cent rabbit erythrocytes suspension. A control experiment was carried out in the same conditions with intact cells in place of protoplasts.

Table 1 shows that protoplasts can produce more toxin more rapidly than intact cells under these conditions.

Addition of an amino-acid mixture ('Difco' casein hydrolysate) at a concentration of $1 \mathrm{mgm} . / \mathrm{ml}$. inhibited toxin formation in both protoplasts and intact cells.

Gooder and Maxted $^{3}$ recently reported that the streptococcal protoplasts could be obtained with either $2 M$ sucrose or $2 M$ sodium chloride as supporting media. In our case, however, the formation of streptolysin $S$ was strongly inhibited in these hyper. tonic media and 1.6 $M$ sucrose, 10 per cent polyethyleneglycol, 0.5 potassium chloride and 0.5 potassium monohydrogen phosphate failed to support the protoplasts of this bacterium. Such media as $0.5 M$ fumarate, malate, malonate, citrate and tartrate supported the protoplasts, but succinate is most satisfactory in view of the inhibitory effect of other salts on toxin formation.

Wo wish to thank Dr. W. R. Maxted for the gift of group $C$ streptococcus and its phage.

Yoshimaru MaruYama

Sadako Sugat

FUGIO EGaMI

Department of Biophysics and Biochemistry,

Faculty of Science, University of Tokyo, Bunkyo-ku, Tokyo. June 26.

1 'Tanaka, K., J. Biochem., 45, 109 (1958).

Maxted, W. R., J. Gen. Microbiol., 16, 584 (1957). Krause, M.

${ }^{3}$ Gooder, H., and Maxted, W. R., Nature, 182, 808 (1958).

\section{Growth of Bacterium coli and Staphylococcus albus in Heavy Water}

Is the mid 1930's when heavy water became available, workers experimenting on its biological effects reported delayed growth, complete inhibition, and morphological changes in many types of organisms including bacteria ${ }^{1,2}$. Some reported normal growth ${ }^{3}$. Recently Walker and Syrett ${ }^{4}$ confirmed the inhibition of autotrophic growth of Chlorella by heavy water but found less inhibition in the presence of glucose.

Growth of two strains of bacteria in buffered nutrient heavy water broth, prepared by redissolving lyophilized aqueous nutrient broth in 99.8 per cent heavy water (Norsk Hydro), was compared with their growth in aqueous medium and in medium with various concentrations of heavy water. Small inocula were prepared by growing and suitably diluting overnight cultures of the test organism in the experimental medium.

In heavy water the growth of both strains was slower than in ordinary water. The specific growth rate in ordinary water was 2.0 times greater for Staphylococcus albus and $2 \cdot 5$ times for Bacterium coli. Even after repeated subculture in 99.8 per cent heavy water medium the organisms were morpho. logically indistinguishable from those grown in ordinary water and the colonial morphology was unchanged.

In lower concentrations of heavy water the doubling time was roughly proportional to the antilogarithm of the concentration of heavy water.

The addition of glucose to heavy water broth produced an effect no greater than in ordinary water broth, and Bacterium coli was able to grow in a 99.8 per cent heavy water medium with glucose and ammonia as sole carbon and nitrogen sources.

ElizaBeTh VAN HoRy

G. C. WARE

Department of Bacteriology,

University of Bristol,

Canynge Hall, Bristol 8. June 16.

1 Lewis, G. N., J. Amer. Chem. Soc., 55, 3503 (1933).

2 Chance, H. L., and Allen, W. C., J. Bact, 51, 547 (1946).

Weiser, H. H., Proc. Soc. Exp. Biol. Med., 36, 151 (1937).

\section{GEOLOGY}

\section{Indications of Glacierization in the Siwalik System in India}

The Indian sub-continent was not subjected to glacial conditions during the Quatenary Era, but its highlands, namely the higher ranges of the Himalayas up to the latitude of about 33. degrees, were.

The Great Ice-age is believed to have commenced everywhere during Lower Pleistocene times, as proved by the occurrence of glacial deposits lying directly over the Pliocene rocks. de Terra ${ }^{1}$, who has studied the glacial geology of the Himalayas, is of the opinion that the Boulder-Conglomerate, the uppermost member of the Siwalik system, corresponds to the second or the Mindel stage of the glacial cycle and the Interglacial interval immediately following it and is, therefore, of middle Pleistocene age. If this is so, the underlying Tatrot and Pinjor stages should represent the first ice advance and belong to lower Pleistocene.

Accepting this suggestion, Pilgrim ${ }^{2}$ considers the Pinjor and Tatrot stages as belonging to the upper Pliocene and not to the lower Pleistocene, particularly 